\title{
Analysis of Factors Enhancing Credit Repayment Among Lowly Endowed Women Farmers
}

\author{
James Obara \\ Egerton University, Njoro, Kenya
}

\begin{abstract}
While credit support is an important factor in enhancing agricultural production, the problem is the restricted accessibility to farm credit by the Lowly Endowed Women (LEW) farmers. The banks and other formal lending institutions consider LEW farmers a risk and/ or not credit worth. To be unveiled yet are the strategies and interventions that ought to be put in place so as to enhance credit repayment by Lowly Endowed Women farmers. The research was done on women farmers in Funyula Sub County, Busia County, Kenya. A sociological inquiry, in form of a survey was used to collected field data based on the views of the LEW farmers on the various credit arrangements to determine which ones were acceptable and could lead to both effective use of credit and high credit repayment rate. In addition to the field survey, case studies were carried out for additional data and to strengthen the findings of the field survey. The target population was the women farmers. All the 15,000 households Funyula Sub County (Ministry of Agriculture, 1997) constituted the accessible population. The study assumed every household had a woman. For case studies, the population was chosen from the on-going or immediate past rural programmes with an informal credit component for lowly endowed people, particularly the women. Sampling of the household was undertaken using a proportionate, stratified random sampling technique on sub locational basis. The sub county had 28 sub locations. All the Sub Locations were represented in the study. A sample of 210 LEW farmers was taken. For the case study, agencies that had a credit component for the lowly endowed people were selected. Three credit programmes run by two agencies with fairly successful record of credit support to the poor were studied. These agencies included an NGO, Kenya Rural Enterprise Programme (K-REP) and a government/ bilateral donor assisted agency, the DANIDA which supported Kitui Agricultural Project (KAP). Field data was collected by the researcher. The Statistical Package for the Social Sciences (SPSS) was used to aid the analysis of the data. Chi-square was used to test the relationship between the variables. The level of significance for the relationship between variables was rejected or accepted at $\mathrm{p} \leq 0.05$ significant level. The findings of the study were: credit rating appeared unpopular method of assessing the credit worth of the respondents and was rejected. On peer pressure, the finding showed a positive relationship between peer pressure and credit repayment among the LEW farmers. The relationship between savings and credit repayment was found to be, statistically not significant. Lastly, the study findings indicated a positive relationship between assurance of continued credit support on completion of the ongoing one and credit repayment.
\end{abstract}

Keywords: Credit Repayment, Lowly Endowed Women Farmers

DOI: $10.7176 / \mathrm{JBAH} / 10-4-05$

Publication date: February $29^{\text {th }} 2020$

\section{Introduction}

While credit support is an important factor in enhancing agricultural production, the problem is the restricted accessibility to farm credit by the Lowly Endowed Women (LEW) farmers. The banks and other formal lending institutions consider LEW farmers a risk and/ or not credit worth. Most of the LEW farmers, in most cases are illiterate or have low education. They do not keep farm records which are usually required to assess their credit worthiness by the formal lending institutions, nor do they have business plans. Other related problems are likely mismanagement of loans given to groups by the group leaders, and the difficulty involved in administering a credit programme to individual LEW for fear of defaulting in servicing loans. To be unveiled yet are the strategies and interventions that ought to be put in place so as to enhance credit repayment by Lowly Endowed Women farmers.

\section{Objectives of the Study}

The purpose of the study was to collect and analyze relevant data from Funyula Sub County and elsewhere and make suggestions for improvement of credit repayments by LEW farmers. The specific objective of the study was to determine high rate of credit repayment by the LEW with respect to:

i. Individual's rating by the group members for credit worth

ii. Peer pressure by the group members on individual credit

iii. Savings requirement before credit offer

iv. Guaranteed qualification for another credit offer at higher level on completion of the ongoing one 


\section{Hypothesis}

The specific objective was translated into the following null hypothesis statements; There is no relationship between:

i. Rating of individuals for credit worthiness by the group members in terms of honesty and financial capability and credit repayment.

ii. Peer pressure, that is, pressure exerted by members of the group on others who borrowed and credit repayment.

iii. Savings mobilization/raising some saving as a requirement to qualify and credit repayment

iv. Guaranteed qualification for another credit offer at a higher level on completion of the on-going one and credit repayment

An attempt to access credit to the disadvantaged groups such as the LEW farmers has been received with mixed results. The ministry of Agriculture and Livestock Development in the 1970s and early 1980s had credit schemes such as the Integrated Agricultural Development Project (IADP), the Farm Input Supply Scheme (FISS), the Smallholder Coffee Improvement Project which were appropriate, as well to the disadvantaged groups such as LEW. Unfortunately, these credit schemes are no longer operational. The programmes suffered from poor loan recovery. It is reported in the National Agricultural Extension Project that the recovery rate was about 23\% (Ministry of Agriculture, 1982). Such recovery rate is too low to sustain a credit programme. Field experience of the investigator with the Ministry of Agriculture is that, the Ministry was ill prepared to administer such credit programmes.

The independent variables of the study were Individual's rating by the group members for credit worth, peer pressure by the group members on individual credit offers, level of personal savings with the group requirement before credit offer and guaranteed qualification for another credit offer at higher level on completion of the ongoing one. The independent variables were measured by rating the responses of the respondents on a five point Likert Scale of $\mathrm{SA}=$ Strongly Agree, $\mathrm{A}=$ Agree, $\mathrm{NS}=$ Not Sure, $\mathrm{D}=$ Disagree and $\mathrm{SD}=$ Strongly Disagree. The farmers were asked to respond to a set of statements related to credit conditions of offering and subsequent credit use. The dependent variable was repayment rate of the credit offered and was measured in terms of number of borrowers paying the credit on schedule.

\section{Research Methodology}

The research was done on women farmers in Funyula Sub County, Busia County, Kenya. According to Ministry of Agriculture (1997), the sub county which had about 15,000 households was chosen because no similar research had been done there, and yet the land has high potential for farming activities. The average rainfall ranges from 1000 to $1400 \mathrm{~mm}$ per annum, with a $60 \%$ reliability and characterized mainly by warm and semihumid climate, much suited for cotton growing (Jaetzold and Schmidt, 1982).

A field survey was carried out in Funyula Sub County. A sociological inquiry, in form of a survey was used to collected field data based on the views of the LEW on the various credit arrangements to determine which ones were acceptable and could lead to both effective use of credit and high credit repayment rate. In addition to the field survey, case studies were carried out for additional data and to strengthen the findings of the field survey as advocated by Casley and Lury (1981). Three case studies were carried out, one was a rural development programme with a credit component for the poor, administered by GoK/bilateral donor agency. The other two case studies were of credit programmes administered by an NGO that accessed credit to the rural community members. The credit programmes had different approaches in the way they were administered to the poor. The investigator visited the institutions, discussed with appropriate Officers in the head office followed by field visits, details are discussed elsewhere in the report.

The target population was the women farmers. All the 15,000 households in Funyula Sub County (Ministry of Agriculture, 1997) constituted the accessible population. For case studies, the population was chosen from the on-going or immediate past rural programmes with an informal credit component for lowly endowed people, particularly the women. Selection of programmes at the national level, rather than limiting to the local ones, was decided upon for comparison purposes.

Sampling of the household was undertaken using a proportionate, stratified random sampling technique on sub locational basis. All the sub locations were represented in the study. This was to ensure a wide representation of the target population. It was important to collect data and get the views across the sublocations since they differ in population characteristics and sizes as suggested by Tuckman (1978), Moher and Kalton (1971). On average, four to ten respondents were drawn from each sub-location, with the variation in numbers dictated by the population size of farmers in each sub-location. The sampling frame was obtained from the records of the Ministry of Agriculture and Livestock Development Technical Assistants (TAs) manning the twenty five sub-locations in Funyula Division. The investigator met and explained the purpose of the study to the Sub County Extension Coordinator (SCAO), in charge of Funyula Sub County. This was followed by another meeting, which was arranged by the DEC for the investigator to meet the Technical Assistants (TAs). The 
meetings were to facilitate development of a sampling frame. Through the office of the Sub County Extension Coordinator (SCAO), each TA was asked to prepare a list of LEW households within the sub-location. A combined list of the households from the TAs formed the sampling frame from which the sample households for the study was selected. Consequently, a sample of 210 LEW households was taken. For a study population of 15,000 , a sample of 210 respondents was considered sufficient. The sample size of 210 respondents was above the minimum recommendation. Nassiuma, 2000; Kathuri and Pals, 1993 both indicate sample size from a study population could be obtained by applying the formula:

$$
\mathrm{n}=\frac{\mathrm{NC}^{2}}{\mathrm{C}^{2}+(\mathrm{N}-1) \mathrm{e}^{2}}
$$

\section{Coefficient}

where $\mathrm{n}=$ Sample size, $\mathrm{N}=$ Population, being15,000), $\mathrm{C}=$ of variation, 0.21 being lowest acceptable value, e $=$ Standard error

(0.02), lowest acceptable value.

$$
\text { Thus, } \mathrm{n}=\frac{15,000 \times 0.2^{2}}{0.21^{2}+(15,000-1)\left(0.02^{2}\right)}=155
$$

For the case study, agencies that had a credit component for the lowly endowed people were selected. Three credit programmes run by two agencies with fairly successful record of credit support to the poor were studied. These agencies included an NGO, Kenya Rural Enterprise Programme (K-REP) and a government/ bilateral donor assisted agency, the DANIDA supported Kitui Agricultural Project (KAP). The choice of the two agencies was influenced by the secondary information that was available about the programmes and the fact that they had different approaches to accessing credit and to credit administration which provided the basis for comparison. Two credit programmes were chosen from the K-REP, while for the government/ bilateral donorassisted programmes, DANIDA supported KAP was chosen over the SIDA supported National Agricultural and Livestock Extension Programme (NALEP). The DANIDA supported KAP was found to be most relevant for the study. The programmes had different approaches of providing access to credit to their target groups and also provided useful information for comparison purposes.

The instruments for the study were developed to address issues in the research objectives and provided data to answer the the hypothesis. They included the questionnaire containing structured items for the field survey, and the questionnaire guide which was used for the case studies. A first draft questionnaire was developed and discussed with members of the Faculty of Education an Human Resources, including members of the Department of Agricultural Education and Extension, Egerton University, Njoro, soliciting expert opinion on its practicability and effectiveness. The questionnaire had two sections. Section one was composed of questions with items with alternative (multiple choice) responses to choose from. However, there were some items that were open ended and these were intended to provide the respondents with the freedom to respond to any reasonable details and extent on the issues raised. Section two of the questionnaire was composed of questions on a Likert scale intended to tap the attitudes and feelings of the respondents. The questionnaire was used to collect primary data on the following items: profiles of the respondents, avenues or structures for credit intervention, various credit arrangements in relation to response to credit, effective use of credit, credit repayment and the effect of credit on emergence of market-oriented farming. A pre-test for reliability of the instrument was done using twenty farmers in Njoro Sub County. Njoro Sub County was used for pre-testing because farmers in Njoro share some commonality on some of the elements that were being investigated in the study and secondly because of its convenience. Crownbanch coefficient alpha $(\alpha)$ was computed for estimation of the internal reliability of the questionnaire, which was found out to be 0.87 , indicating that the instrument was reliable. According to Borg and Gull (1983) a reliability level above 0.75 is acceptable.

A questionnaire guide rather than a structured questionnaire was used in the case studies to collect information and data on issues of the programmes, and for interviewing the programme proponents and implementers. The items in the questionnaire guide were organizational arrangements required for credit offer, conditions of credit offer, recovery arrangements and effects of credit that was offered.

The investigator carried out the actual data collection. Where sampled respondents were never found, the closest neighbour was chosen as a replacement. The questionnaire items were read to the respondents in local vernacular language to solicit their responses. On the case studies a questionnaire guided by the questionnaire guide was used. The interview was followed by examination of the project documents including field evaluation reports which were supplied, providing the details being studied in the case study. A field visit to Funyula Financial Services Association (FSA) was arranged. Here arrangements were made and the board of governors, employees and a shareholder in the FSA were interviewed by the investigator. For the Kitui Agricultural Project (KAP), the investigator made a scheduled visit to Kitui District Headquarters, where arrangements were made to interview various officers directly involved in the implementation of the programme, the Project Coordinator, the Agriculturist, the Community Development Officer and the Monitoring Officer. Additional interviews were carried in the field to the farmers. A farmer was interviewed individually followed by farmers in a group. In 
addition, project documents with valuable information about issues under the study were provided.

Responses were coded, organised and fed into the computer for analysis. The Statistical Package for the Social Sciences (SPSS) was used to analyse the data. The hypothesis was analysed using chi-square test for the relationship between the variables. The hypothesis was rejected or accepted at $\mathrm{p} \leq 0.05$ significant level.

\section{Results and Discussions}

3.1 Relationship between credit rating for credit and repayment

The results of the field study are shown in Tables 1 and 2 appear not to agree with the prediction. From Table 1, Ninety two $(44.0 \%)$ respondents agreed that individual rating for credit would result into higher credit repayment, $99(47.4 \%)$ agreed while $18(8.6 \%)$ were not sure. From these results, there are almost equal numbers for those who agree that individual rating for credit could improve repayment and those who disagreed that it could not. The result of the chi-square test for the relationship between credit rating and credit repayment is shown in Table 2. From the table, the chi-square $\left(\mathrm{x}^{2}\right)$ test for the relationship between credit rating and repayment was 0.535 , indicating that the relationship is not significant $(p \leq 0.05)$, hence confirming the hypothesis that: There is a negative relationship between credit rating and credit repayment among the LEW. Credit rating is aimed at sorting out only those with fair chance of repayment. The results are contrary to the expectation of positive relationship between credit repayment and credit rating. Under the LEW circumstances worthiness may not necessarily be in terms of assets they own but factors such as trustworthiness, background of the individual, individual's associations and other social factors could count most. The vetting was not by the credit agency but by fellow community members who stand to benefit from the sustenance of that credit facility. Why then does credit rating not result in higher credit repayment? More research needs to be done in this area.

\subsection{Relationship between Peer Pressure and credit Repayment}

The results of the study are shown in Tables 1 and 2. From Table1, 76(36.2\%) agreed that peer pressure would increase credit repayment rates among the LEW, 117(55.7\%) did not agree while 17(8.1\%) were not sure. The chi-square test for the relationship between peer pressure and credit repayment (Table 2) was 0.028 indicating that the findings are significant $(\mathrm{p} \leq 0.05)$. Thus, there is a positive relationship between peer pressure and credit repayment among the LEW. Peer pressure is applied in situations where the group guarantees one of their members and it (group) would not like the groups reputation of credit repayment be spoiled because one of their members had defaulted. Defaulting by a member would affect the entire group not accessing any more credit. The threat of losing access to future credit and loss of group credibility were the forces behind peer pressure on their colleagues (Zeller, 1998; Esipisu,1995). The results indicate positive relationship between credit repayment and peer pressure. However, peer pressure appears only to apply in situations where the relationships within the group is warm (Esipisu, 1995). Where there are some conflicts within the group perhaps peer pressure may not successfully apply. The exact reason for good repayment of credit through group guarantee is not clear but one of the likely reasons for good repayments rates for individual credit under group security could be social pressure and fear of social isolation in case of defaulting. This is true in relatively small groups where relationship among the members is warm and every member is willing to conform to group norms and values. Usually under this arrangement the groups are responsible for screening and enforcement functions, which the credit agencies could have found difficult to attain at reasonable cost, thus reducing the costs of the credit administration by the lending agency (Zeller, 1998).

\subsection{Relationship between Savings and credit Repayment}

Table 1 and 2 show the findings of the study. From Table 1, 157(75.5\%) of the respondents agreed that saving requirement to qualify for credit improved repayment, 39(18.8\%) disagreed while $18(8.8 \%)$ were not sure. When tested for the relationship between saving requirement and repayment, a chi-square test was 0.067 indicating that the association between credit repayment and savings mobilisation is not significant $(\mathrm{p} \leq 0.05)$. However, experiences with credit programmes for low-income groups elsewhere indicate that sustainable credit programmes are built on sound savings mobilisation arrangements built within the programme. Esipisu et al (1995), Kkandiker and Khalily, (1996); Michnink, (1996) stress the usefulness of a saving component in any credit programme. Regular savings of the business income act as security for loan to groups and help groups build a capital base which could be used for future re-lending of the members in the absence of credit agencies. These are some of the benefits of a strong savings component in a credit programme. Savings as a requirement for credit qualification could also be used as an indication of practical commitment to credit need. There is some sacrifice in raising some savings for purposes of qualifying for credit.

3.4 Relationship between Assurance of Continued Credit Offering on completion of the ongoing one and Credit Repayment:

The findings of the field survey are shown in Tables 1 and 2. From Table 1, it was observed that 187(89\%) 
respondents agreed that assurance of continued credit offering on completion of the on going one would improve credit repayment while 5(2.4\%) disagreed and 18(8.6\%) were not sure. The chi-square test for association between credit repayment and assurance of continued credit support on completion of the on going one was 0.000 as shown in Table 1 indicating the findings are significant $(\mathrm{p}<0.05)$. Thus, there is a positive relationship between credit repayment and assurance of continued credit offer on completion. When assured of continued credit, usually there is more compliance to repayment than where one is not sure of when the next credit will be. Pride Africa, an NGO with widespread credit programmes in the country operated on this kind of credit arrangements. On completion, the applicant was not only assured of another credit but also qualified for more credit at a higher level (Pride Africa, 1996). Similar arrangements with resulting good response to credit repayments were reported in the Malawi Rural Finance Company in which there was good repayment because assurance of continued credit offers on completion was given (Diagne, 2000, Vincent,1995)

There are a number of other factors that may not have been discussed in this research that could bring about poor credit repayment. Attention to those factors should as well be taken into consideration in designing a credit programmes for LEW farmers. Bhupat and Mellor (1993) outlined low profitability than anticipated, adverse weather conditions, lack of market tie-ups for the inputs and produce, over financing relative to the borrowers capacity, under financing, diversion of credit to other uses among other factors that ought to be put in consideration

Table 1: Factors affecting repayment of credit among the LEW

\begin{tabular}{ccccc}
\hline Factors & Response & Frequency & Percent & Valid Percent \\
\hline
\end{tabular}

Individual rating for

credit results into

higher repayment
Peer pressure result into

Higher credit repayment

Savings requirement to qualify for credit improves repayment rates

Savings mobilisation be focussed on specific project

Assurance of continued credit offer on completion of the ongoing one could result into higher repayment

\begin{tabular}{|c|c|c|c|}
\hline Agree & 92 & 43.8 & 44.0 \\
\hline Disagree & 99 & 47.1 & 47.4 \\
\hline Not sure & 18 & 8.6 & 8.6 \\
\hline Sub-total & 209 & 99.5 & 100.0 \\
\hline No response & 1 & 0.5 & \\
\hline Total & 210 & 100.0 & \\
\hline Agree & 76 & 36.2 & \\
\hline Disagree & 117 & 55.7 & \\
\hline Not sure & 17 & 8.1 & \\
\hline Total & 210 & 100.0 & \\
\hline Agree & 157 & 74.8 & 75.5 \\
\hline Disagree & 39 & 18.6 & 18.8 \\
\hline Not sure & 12 & 5.7 & 5.8 \\
\hline Sub-total & 208 & 99.0 & 100 \\
\hline No response & 2 & 1.0 & \\
\hline Total & 210 & 100.0 & \\
\hline Agree & 142 & 67.6 & \\
\hline Disagree & 18 & 8.6 & \\
\hline Not sure & 50 & 23.8 & \\
\hline Total & 210 & 100.0 & \\
\hline Agree & 187 & 89.0 & \\
\hline Disagree & 5 & 2.4 & \\
\hline Not sure & 18 & 8.6 & \\
\hline Total & 210 & 100.0 & \\
\hline
\end{tabular}

$\mathrm{n}=210$ 
Table 2: Summary of the findings for the relationship between credit repayment and the credit conditions

\begin{tabular}{|c|c|c|c|c|}
\hline Hypo. (으) & $\begin{array}{l}\text { Independent } \\
\text { Variable } \\
\end{array}$ & $\begin{array}{l}\text { Dependent } \\
\text { Variable } \\
\end{array}$ & $\begin{array}{l}\text { Chi-square test } \\
\left(\mathrm{x}^{2}\right)\end{array}$ & Remarks \\
\hline (i & Credit rating & Credit repayment & 0.535 & Rejected \\
\hline (ii) & Peer pressure & Credit repayment & 0.028 & Accepted \\
\hline (iii) & Savings requirement & Credit repayment & 0.067 & Rejected \\
\hline (iv) & $\begin{array}{l}\text { Assurance of continued } \\
\text { credit offer on completion of the } \\
\text { ongoing one }\end{array}$ & Credit repayment & 0.000 & Accepted \\
\hline
\end{tabular}

\section{Findings and Policy Implications}

i. Credit Rating

Credit rating of an individual is one of the criteria that is usually applied by Credit Agencies to assess whether to give or decline giving the credit to the applicant. In this research, however, credit rating appeared unpopular method of assessing the credit worth of the respondents and was rejected. Under the LEW circumstances worthiness, perhaps may not necessarily be in terms of assets one owns but other social factors such as trustworthiness, background of the individual, individual's associations could count most among members of the group. Credit rating should be by fellow community members who stand to benefit from the sustenance of that credit facility and not by the lending agency.

ii. Peer Pressure

The findings of the study indicated a positive relationship between peer pressure and credit repayment among the LEW farmers. Peer pressure is applied in situations where the group guarantees one of their members and it (group) would not like the groups reputation of credit repayment be spoiled because one of their members had defaulted. Credit facility to the LEW could best be administered to individuals through groups. Besides, members of groups with a history of a good repayment record could be given priority in accessing credit facility. However Peer Pressure and credit Repayment works best where the relationship among members of the group is warm

iii. Savings Mobilization

The relationship between savings and credit repayment was found to be, statistically not significant. However, experiences with credit programmes for low-income groups elsewhere indicate that sustainable credit programmes are built on sound savings mobilisation arrangements built within the programme. Savings as a requirement for credit qualification could also be used as an indication of practical commitment to credit need. There is some sacrifice in raising some savings for purposes of qualifying for credit.

iv. Assurance of Continued Credit Offering on completion of the ongoing one

The study findings indicated a positive relationship between assurance of continued credit support on completion of the ongoing one and credit repayment. When assured of continued credit, usually there is more compliance to repayment than where one is not sure of when the next credit will be. This form of lending arrangement seem positive with borrowers, perhaps as a sure way to continuously access credit. Therefore, credit agencies even to the disadvantaged groups such as the LEW farmers should provide for mechanisms for easy and continuous credit access to their 'customers', the on going credit beneficiaries.

\section{References}

A Guide to Working with Informal Financial Institutions (2014). Retrieved on 20/9/2019, www.technoserve.org. Aredo, D. (1993). The Informal and Semi-Informal Finance Sectors in Ethiopia: A study of the Iqqub, Iddir and Savings and Credit Co-operatives. A E R C Research Paper 21, AERC, Nairobi Kenya.

Aryeetey, E. (1995). Filling the Niche Informal Finance in Africa. African Economic Research consortium (AERC) Nairobi Kenya.

Aryeetey, E. and Gockel, F. (1991). Mobilizing Domestic Resources for Capital formation in Ghana: the Role of the Informal Financial Sector. A E R C Research Paper 3, AERC, Nairobi Kenya.

Bahemuka, J.M. (1985). Social - Anthropological Survey of small scale farming in Western Kenya. On farm grain storage project,. Ministry of Agriculture and Livestock Development. Maseno, Kenya.

Benor D. \& Baxter M. (1984). Agricultural Extension., The Training and Visit System. World Bank, Washington D.C.

Bhupat, M.D. and Mellor, J.W. (1993). Institutional Finance for Agricultural Development, An Analytical Survey of Critical Issues. (IFPRI), Washington D.C.

Borg, W.R. and Gall, M.D. (1983). Educational Research, An introduction. New York; Longman.

Casley D.J. \& Lury, D.A (1981). Data collection in Developing countries. New York, Oxford University Press. 
Cheruiyot, A. and Kioko, K. (1999). Financial Services Associations. Evaluation Report No. 32, K-REP, Nairobi, Kenya.

Diagne, A. (2000). Design and Sustainability Issues of Rural Credit and Savings Programs: Findings from Malawi. Policy Brief No. 12, IFPRI, Washington D. C.

Esipisu, E., Nasubo, G., Obuya, M., Kioko, K. (1995). Lending through Chikola Groups four years of experince. Evaluation Report No. 28, K-REP, Nairobi, Kenya.

Goetz A.M. (1996) Who Takes The Credit: Gender, and Control over Loan Use in Rural Credit Programs in Rural Credit Programmes in Bangladesh. World Development.

Goodluck, C. and Neema, M. (2017). Loan Repayment Performance of Clients of Informal Lending Institutions: Do Borrowing Histories and Dynamic Incentives Matter? The International Journal of Development Issues. Vol.16. No.3. Emerald Publishing Limited.

Government of Kenya (1996). National Development Plan (1997 - 2001).

Huizinga, B. (199). Paper presented at the Regional International Course in Rural Extension (ICRE). Course theme, New perspectives in Rural Extension : Challenges and Prospects. Egerton University, Njoro, Kenya.

International Fund for Agricultural Development (IFAD), (2000): Rural Financial Services Project, PreAppraisal (IFAD Project Ghana), Rome Italy.

Kathuri, N.J. and Pals D.A. (1993). Introduction to Educational Research. Educational Media Centre (EMC) Egerton University, Njoro, Kenya.

Khandker, S.R. and Khalily, B. (1996). The Bangladesh Rural Advancement Committee's Credit Programmes Performance and Sustainability. The World Bank, Washington, DC.

Ministry of Agriculture and Livestock Development (1999). Agricultural and Livestock Extension Policy Guidelines. Ministry Headquarters, Nairobi.

Ministry of Agriculture and Livestock Development (2000). The National Agricultural and Livestock Extension Programme (NALEP). Ministry Headquarters, Nairobi.

Ministry of Agriculture and Livestock Development (1997). Divisional Agricultural and Livestock Extension Officer Annual Report, Funyula Division.

Ministry of Agriculture and Livestock Development (1982). Agricultural and Livestock National Agricultural Extension Project. Ministry Headquarters, Nairobi.

Ministry of Agriculture and Livestock Development (1996). District Annual Report, Busia District.

Mitchnink D. (1996). Operational Guidelines for Credit Projects (Mimeo typescript).

Mosher, C.A. and Kalton, G. (1971). Survey Methods in Social Investigation. Gower, England.

Nassiuma, D. K. (2000). Survey Sampling: Theory and Methods. Nairobi University, Kenya. Nairobi University Press.

Pride Africa. Pride Africa at a Glance 4 (mimeo typescript).

Tuckman, B.W. (1978). Conducting Educational Research. Harcourt Brance Jovnonich Inc. New York USA.

Vincent, F. (1995) Alternative Financing of Third World Development Organisations and NGOs. Vol I Development innovations and Networks (IRED) Geneva, Switzerland. 